\title{
The Significance of Parental Involvement in the Development in Infancy
}

\author{
Yanhui Liu, $\mathrm{PhD}$ \\ Ohio University, Athens, Ohio, United States \\ (iD) https://orcid.org/0000-0002-6314-2044 \\ Mona F. Sulaimani, $\mathrm{PhD}$ \\ King Abdulazizi University, Jeddah, Saudi Arabia \\ (iD https://orcid.org/0000-0003-4495-1249 \\ John E. Henning, PhD \\ Monmouth University, West Long Branch, New Jersey, United States \\ iD https://orcid.org/0000-0002-1297-8693
}

Contact: yl260611@ohio.edu

\section{Abstract}

The earliest experiences of children can ensure their future success, and parenting is noted to be an influential factor (Bronfenbrenner, 1979; Lamb et al., 2002). Many researchers theorized that parental involvement could encourage children to actively engage and improve their academic achievement in schools (Epstein, 2018). However, less attention was paid to the significance of parental involvement in infants' development. This article explores the role of parental involvement in infants' development by reviewing and discussing abundant relevant studies. This study recommends that parental involvement should be considered as an affluent resource and a useful tool because it could provide rich information about infants' individual needs and positively help infant teachers to improve their instructional skills.

Keywords: parental involvement, infants' development, achievement

Date Submitted: January 19, 2020 | Date Published: June 26, 2020

\section{Recommended Citation}

Liu, Y., Sulaimani, M. F., \& Henning, J. E. (2020). The significance of parental involvement in the development in infancy. Journal of Educational Research and Practice, 10, 161-166. https://doi.org/10.5590/JERAP.2020.10.1.11

\section{Introduction}

A traditional way of thinking regarding parental involvement often focused on how parents support their children's education and meet the needs of schools. For example, parents attended the parent-teacher meetings, helped their children finish the homework, and volunteered in their child's classroom a few days a month. A good deal of researches began to focus on how parents were involved in school events or classroom activities (Reinke et al., 2019; Smith \& Sheridan, 2019), and suggested that it is necessary to find strategies to 
support parental involvement because its influence on children's achievement and performance (Grace \& Gerdes, 2019; Tan et al., 2019). According to the study conducted by LaBahn (1995), parental involvement is the level of active participation a parent had in their children's education, and this definition was supported by Gonzalez-Mena (2008). In addition, parental involvement is viewed as an important factor for children's educational achievement at home and in the school (Boonk et al., 2018; Dotterer \& Wehrspann, 2016; Epstein, 2018; LaBahn, 1995; Nevski \& Siibak, 2016; Smith \& Sheridan, 2019; Tan et al., 2019; Thompson et al., 2017).

\section{The Benefits of Parental Involvement}

Teachers can have a better understanding of infants by implementing parental involvement because infants spend much more time with their parents than any other people. Parents are infants' first teacher and continue to play an active role in their education and lives. According to the study conducted by Bronfenbrenner (1979), students' achievement was always shaped by their life outside the school and highlighted the importance of parents' role. Therefore, parents' words, behaviors, and beliefs would have a great deal of influence on their children's development, even in the development in infancy (Hedenbro \& Rydelius, 2019; Lamb et al., 2002). Involving parents in their children's education not only increases the child's achievement (Nevski \& Siibak, 2016; Pineda et al., 2018) but also helps parents to understand their children and teachers better to improve their instruction. Followings are the benefits of parental involvement: Some researchers considered that parental involvement in young children's education can (a) promote infants' social-emotional development (Hedenbro \& Rydelius, 2019; Langevine, 2020); (b) improve student achievement (Daniel et al., 2016; Epstein, 2018; Otani, 2019; Puccioni, 2018), especially the linguistic achievement (Tan et al., 2019); (c) promote better grades, test scores, school attendance (Epstein, 2018; Mata et al., 2018), and school behavior (LaBahn, 1995; Mata et al., 2018; Roy \& Giraldo-GarcĆa, 2018); (d) help students have better performance and motivate students (Silinskas \& Kikas, 2019); (e) help parents increase their interaction and discussion with their children and are more responsive and sensitive to their children's social, emotional, and intellectual developmental needs at home and in the school (Mata et al., 2018); (f) offer opportunities for parents and teachers to create mutual respect and understanding (e.g., attending school meetings, supporting school events, talking to teachers or volunteering at the school; Mata et al., 2018); (g) help parents and teachers build a good relationship so that parents can have a better understanding of the teacher's job and school curriculum (Epstein, 2018; Owen, 2016); and (h) help teachers acquire a better understanding of families' cultures and diversity, and form deeper respect for parents' abilities and time (Epstein, 2018).

\section{Barriers to Parental Involvement}

Though numerous studies had indicated that parental involvement was very important in young children's education (Lamb et al., 2002), there were some barriers to parental involvement. Barriers for parents to be involved in school included feeling unwelcome in school, the lack of interest or caring, time constraints of working parents, and feeling that their involvement was not a big deal to their children's education based on teachers' attitude (Hornby \& Blackwell, 2018).

In addition to the barriers to parental involvement, teachers' attitudes and beliefs regarding parental involvement were considered as the first critical barrier. Chan (1995) had indicated that parental involvement requires teamwork and cooperation between parents and schools. Therefore, if teachers consider parents as less important, teachers would seldom design school activities or homework that can involve parents. Therefore, parents would have fewer opportunities to be involved in their children's education. 
Parents themselves are considered as the second barrier. Parents' attitude about their role is important. If they do not view their role in their children's education as important, it leads to disconnections between home and school. If parents do not know what happens in their children's classroom, they may lose the ability to judge their children's school performance and developmental level.

Lack of time is viewed as the last barrier. At present, both mom and dad are employed. Some parents communicate with teachers when they picked their children up from school. Some parents do not often share information with teachers because they do not have much time. Therefore, parental involvement during the childcare day was usually limited to arrival and pick-up time. However, parental involvement can be a significant way to help students to form a good adjustment between home and school and be beneficial to both parent and teacher.

\section{Strategies for Implementing Parental Involvement}

Though there are barriers to parental involvement, the link between parental involvement and student achievement is strong (Epstein, 2018; Hornby \& Blackwell, 2018). It is believed that involving parents can make a positive impact on children and their school (Epstein, 2018; Puccioni, 2018; Thompson et al., 2017). The remainder of this article will discuss three main aspects that infant teachers and parents can implement to improve their children's learning and support a successful adjustment between home and the childcare center.

\section{Teachers' Attitudes}

Infants have different emotional feelings, individual needs, and various interests in each classroom. Because infants cannot express their feelings and needs verbally, it is hard for infant teachers to capture their complex emotional and social needs all the time. Teachers would meet challenges if they cannot fully understand infants' special needs. Thus, it is significant for teachers to know their students well and understand them by involving infants' parents. Teachers perspectives and attitudes regarding parental involvement would be influential.

Teachers should be aware that parents can provide rich information about their child because parents know their babies best. Therefore, the school board should support parental involvement. Because many childcare centers may not have the school board, educators should support parental involvement. For example, educators can design a lecture or seminar in which the topic is related to parental involvement. It can provide teachers with the importance of parental involvement.

After teachers realize the importance of parental involvement, teachers can come up with some ideas about how to involve parents in their children's developmental process. For example, teachers can involve parents in the decision-making process. Teachers can hold a short parent-teacher meeting on a weekly or monthly basis, or they can share weekly journals via email. Both teachers and parents can gain a better understanding of their children by communicating frequently.

Teachers can invite parents to share concerns about their babies and decide individual goals for them. By listening to parents carefully, teachers can find out and understand parents' concerns and expectations about their child's daily care. Teachers should encourage parents to share in meetings which will help understand various family backgrounds and cultural barriers. 
Liu et al., 2020

\section{Parents' Attitudes}

Parents play a critical role in children's early life (Alimohammadi et al., 2017; Bronfenbrenner, 1979; Lamb et al., 2002). Some of the parents may just drop off and pick up their kids from a childcare center because they just need someone to take care of their babies when they are working. If parents view their roles as a significant part of their children's education, they may be more willing to attend school activities and interact with teachers on a regular basis.

Parents can be invited to attend a meeting with the director at the childcare center. During this meeting, a discussion about the significance of parental involvement in infancy should be shared. It is an effective way for both teachers and parents to be aware of the importance of parents' role.

Parent-teacher meetings are another useful tool for teachers and parents to communicate with each other. In this meeting, both teachers and parents can share their ideas and concerns about the infants while setting goals for their child's development. Based on the information in this meeting, parents can gain a better image of the school work, and teachers can have a better understanding of students' complex cultural backgrounds, needs, and interests.

Teachers can design outdoor activities that can involve infants' parents at the school. The presence of parents in the school is an important factor in their infants' adjustment to school because it represents a link between home and school. For example, going on a walk or organizing play outside with parents can be a good way to involve families. Infants will build a good relationship with not only parents but also other caregivers during outdoor time.

Infants' activities can be documented with pictures. Teachers can post or email parents the pictures of activities if the parents cannot be present. In this way, parents can still be familiar with their babies with the environment the child has been encountered. Pictures can be a unique way to share information relating to parental concerns about their child. For example, if an infant is having any emotional expressions, pictures can show that they can engage with people and materials, and enjoy the school environments; this will alleviate parent concerns that their child is crying all day.

\section{Time}

Time is limited for both parents and teachers. Parents who are employed can usually only afford the "dropoff" and "pick-up" times. Teachers who are working in the childcare center also have demands on their time and often have their personal things that take up their time. Therefore, even though parents and teachers are aware of the importance of parental involvement, they still need to find ways to exchange information.

Teachers can establish a family contact list, making phone calls and sending emails to parents. Weekly emails can include pictures of the activities that are completed at the center.

Teachers can provide parents with infants' materials and activities that can be done at home. Many times, parents do not know what activities to do with their infants. According to Olibie (2014), having a parental involvement component in the home enhanced the curriculum at school. The more parents are involved at home, the more likely the child will succeed.

Teachers can use technology to share information. They can set up a website for sharing the information with parents and allow infants' parents to share ideas with others. Parents can access information online anytime. Therefore, they can control their own time and be free to share when they have a free moment. 


\section{Conclusion}

All research findings indicated that parental involvement significantly increases in children's achievement in education. More specifically, Lamb and colleagues (2002) theorized that parental involvement plays a critical role in the development in infancy. As Douville-Watson et al. (2003) said, "the caregivers can develop tasks and activities that promote interactional synchrony between everyone involved, to teach parents and children the skills" (p. 193). By talking to and listening to parents, teachers can reflect on their instruction to meet the needs of the infants in their care. Thus, this study recommends that all educators take action to encourage and support parental involvement in the development in infancy through a variety of ways.

\section{References}

Alimohammadi, N., Jafari-Mianaei, S., Hasanpour, M., Banki-Poorfard, A. H., \& Sadat Hoseini, A. S. (2017). Parents' role before and during infancy: an islamic perspective. Iranian Journal of Neonatology, $8(4), 65-73$.

Boonk, L., Gijselaers, H. J., Ritzen, H., \& Brand-Gruwel, S. (2018). A review of the relationship between parental involvement indicators and academic achievement. Educational Research Review, 24, 10-30.

Bronfenbrenner, U. (1979). The ecology of human development: Experiments by nature and design. Harvard University Press.

Chan, W. P. (1995). The impact of the Parent-Teacher Association (PTA) on a secondary school in Hong Kong (Unpublished dissertation). University of Hong Kong.

Daniel, G. R., Wang, C., \& Berthelsen, D. (2016). Early school-based parent involvement, children's selfregulated learning and academic achievement: An Australian longitudinal study. Early Childhood Research Quarterly, 36, 168-177.

Dotterer, A. M., \& Wehrspann, E. (2016). Parent involvement and academic outcomes among urban adolescents: Examining the role of school engagement. Educational Psychology, 36(4), 812-830.

Douville-Watson, L., Watson, M. A., \& Wilson, L. C. (2003). Infants and Toddlers: Curriculum and teaching. UN Publications.

Epstein, J. L. (2018). School, family, and community partnerships: Preparing educators and improving schools. Routledge.

Gonzalez-Mena, J. (2008). Foundations of early childhood education: Teaching children in a diverse society. McGraw Hill.

Grace, M., \& Gerdes, A. C. (2019). Parent-teacher relationships and parental involvement in education in Latino families. Contemporary School Psychology, 23(4), 444-454.

Hedenbro, M., \& Rydelius, P. A. (2019). Children's abilities to communicate with both parents in infancy were related to their social competence at the age of 15. Acta Paediatrica, 108(1), 118-123.

Hornby, G., \& Blackwell, I. (2018). Barriers to parental involvement in education: An update. Educational Review, 7o(1), 109-119.

LaBahn, J. (1995). Education and parental involvement in secondary schools: Problems, solutions, and effects. Educational Psychology Interactive. http://www.edpsycinteractive.org/files/parinvol.html

Lamb, M., Bornstein, M., \& Teti, D. (2002). Development in infancy: An introduction. Lawrence Erlbaum Associates. 
Langevine, J. A. E. (2020). Parental involvement and academic achievement of middle school: Hispanic American students in South Texas (Doctoral dissertation, Grand Canyon University).

Mata, L., Pedro, I., \& Peixotoa, F. J. (2018). Parental support, student motivational orientation and achievement: The impact of emotions . International Journal of Emotional Education, 10(2), 77-92.

Nevski, E., \& Siibak, A. (2016). The role of parents and parental mediation on o-3-year olds' digital play with smart devices: Estonian parents' attitudes and practices. Early Years, 36(3), 227-241.

Olibie, E. I. (2014). Parental involvement in curriculum implementation as perceived by Nigeria secondary school principals. Journal of Education and Learning, 3(1), 40-51.

Otani, M. (2019). Relationships between parental involvement and adolescents' academic achievement and aspiration. International Journal of Educational Research, 94, 168-182.

Owen, A. N. (2016). Forming collaborative parent-teacher relationships to increase parental involvement Independent Studies and Capstones, 728. https://digitalcommons.wustl.edu/pacs_capstones/728

Pineda, R., Bender, J., Hall, B., Shabosky, L., Annecca, A., \& Smith, J. (2018). Parent participation in the neonatal intensive care unit: Predictors and relationships to neurobehavior and developmental outcomes. Early Human Development, 117, 32-38.

Puccioni, J. (2018). Parental beliefs about school readiness, home and school-based involvement, and children's academic achievement. Journal of Research in Childhood Education, 32(4), 435-454.

Reinke, W. M., Smith, T. E., \& Herman, K. C. (2019). Family-school engagement across child and adolescent development. School Psychology, 34(4), 346.

Silinskas, G., \& Kikas, E. (2019). Parental involvement in math homework: Links to children's performance and motivation. Scandinavian Journal of Educational Research, 63(1), 17-37.

Smith, T. E., \& Sheridan, S. M. (2019). The effects of teacher training on teachers' family-engagement practices, attitudes, and knowledge: A meta-analysis. Journal of Educational and Psychological Consultation, 29(2), 128-157.

Tan, C. Y., Lyu, M., \& Peng, B. (2019). Academic benefits from parental involvement are stratified by parental socioeconomic status: A meta-analysis. Parenting. Advance online publication. https://doi.org/10.1080/15295192.2019.1694836

Thompson, A. M., Herman, K. C., Stormont, M. A., Reinke, W. M., \& Webster-Stratton, C. (2017). Impact of Incredible Years on teacher perceptions of parental involvement: A latent transition analysis. Journal of School Psychology, 62, 51-65.

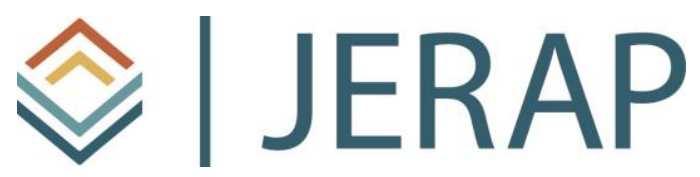

The Journal of Educational Research and Practice is a peerreviewed journal that provides a forum for studies and dialogue about developments and change in the field of education and learning. The journal includes research and related content that examine current relevant educational issues and processes. The aim is to provide readers with knowledge and with strategies to use that knowledge in educational or learning environments. JERAP focuses on education at all levels and in any setting, and includes peer-reviewed research reports, commentaries, book reviews, interviews of prominent individuals, and reports about educational practice. The journal is sponsored by the Richard W. Riley College of Education and Leadership at Walden University, and publication in JERAP is always free to authors and readers. 